AGRICULTURE AND BIOLOGY JOURNAL OF NORTH AMERICA

ISSN Print: 2151-7517, ISSN Online: 2151-7525, doi:10.5251/abjna.2013.4.3.268.274

C 2013, ScienceHuß, http://www.scihub.org/ABJNA

\title{
Thysanoptera survey on Vicia faba (broad bean) in the arid Biskra region of Algeria
}

\author{
S. Razi ${ }^{1,4}$, M., Laamari ${ }^{2}$, S. Ouamen ${ }^{3}$, E.C. Bernard ${ }^{4}$ \\ 1,4 Departement of Agriculture. University Mohamed Khider Biskra, B.P 145 RP Biskra, \\ Algeria.sabah_razi@yahoo.fr \\ ${ }^{2}$ Departement of Agriculture. University Hedj Lakhdar Batna. \\ ${ }^{4}$ Entomology and Plant Pathology University of Tennessee, Knoxville, TN \\ ABSTRACT
}

A survey of thrips on broad bean plants was conducted during 2010-2011 in three sites of Biskra, whitch is an arid province in Algeria. Scouting for thrips was carried out on plants and flowers of three fields from three locations: Sidi-Okba, M'ziraa and El-Outaya. Seven thrips species belonging to six genera were recorded. Melanthrips fuscus, Aeolothrips intermedius, Rhipidothrips gratiosus, Frankiliniella occidentalis, thrips physapus, Thrips angusticeps and Odontothrips loti. The two last species were the most abundant in the three locations. Aeolothrips intermedius was the most abundant species in El-Outaya. Majority of the thrips are cosmopolitan in distribution and recorded as pest species, they can harm broad bean crop. These include Frankliniella occidentalis that may transmit Tospovirus.

Key words: Thrips, Biskra, Broad bean

\section{INTRODUCTION}

Broad bean (Vicia faba L.) is one of the most cultivated plants of legumes in Mediterranean countries. It remains the most important leguminous food crop in Algeria, covering an area of 58,000 hectares and generating a total yield of 254,000 tons (Anonymous, 1990). Algeria is the higher generating of broad bean in the word (Brink \& Belay, 2006). positively the soil productivity for the cereal crops grown in rotation (Zeghouane, 1991).

The Biskra province is a transition region between the Northern and Southern Algeria in terms of morphological and bio-climatic (fig 1), located SouthEast of Algeria. It covers a large area of over 21,671 $\mathrm{km}^{2}$. This region satisfies almost $70 \%$ of national fresh bean requirements in Algeria.

Besides being an important food crop, it contributes to feed and fodder supply for livestock and affect

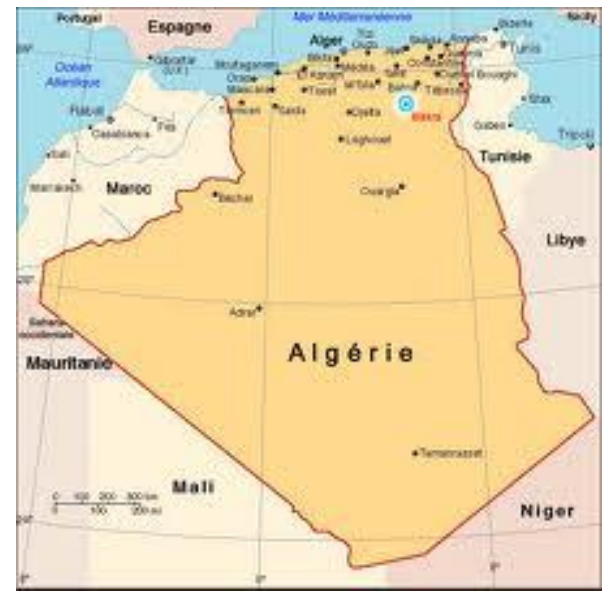

Fig. 1: Location of Biskra Province in Algeria. 
Vicia faba (broad bean) is seriously damaged by various pests. Thrips are among the most serious of these pests, and are listed as a major insect pest in the Mediterranean region (Sexana, 1991).

Thrips are Insect belonging to the order of Thysanoptera, they are considered as a very important order, it includes, about 7400 species (Mound, 2007), more of these species are considered of great economic importance because they harm plants in many ways, such as damages on leaves, flowers and fruits.

Most thrips are tiny and barely visible, they usually are $1-2 \mathrm{~mm}$ long, the smallest are about $0.5 \mathrm{~mm}$ and the largest found in the tropics are about $14 \mathrm{~mm}$ (Lewis, 1973). They are found in flowers and various parts of the plant, and often pupate or spend part of their life cycle in soil or ground litter. Thrips have elongate bodies, which is often slightly to strongly flattened dorso-ventrally, antenna are 4 to 9 segmented.

The mouthparts are of the sucking type, and the proboscis is a stout conical asymmetrical, structure, and located posteriorly on the ventral surface of the head. The labrum forms the front the sides; one mandible (Triplehorn and Johnson, 2004)

Pest thrips use their asymmetrical paired mouthparts to puncture cells on the leaf surface, and then ingest or suck plant juices.

Thrips damage can be quite variable depending upon the pest species and host or cultivar. Some thrips may prefer feeding on the flowers, while others will be more readily attracted to the foliage. Typical flower damage includes browning and early flower drop Ananthakrishanan \& Gopichandran (1993) Thrips feeding damage on foliage can resemble other plant feeders with symptoms such as bronzing, flecking, silvering, and curling. Fruit damaged by thrips may be scarred, deformed or aborted.

Direct physical damage by thrips feeding can reduce crop yields or result in lost market value. Depending upon the host, some levels of thrips populations may be tolerable.

Even when direct thrips damage can be sustained by the host, the ability of thrips to transmit tospoviruses must be considered.The major tospoviruses vectored by thrips include: Tomato Spotted Wilt Virus and Impatiens Necrotic Spot Virus. Virus symptoms may resemble other plant disease symptoms or nutritional issues. Wilting, black streaking, necrotic black spots, chevrons, or concentric circles of light and dark coloration are symptoms of viral infection.

Thrips are not commonly recognized as being a problem by Biskra growers, but they can cause serious damage and infestation does result in major commercial losses due to direct feeding and virus transmission. Currently, there is a lack of knowledge regarding the most common thrips species on broad bean in Biskra.

The aim of this study was to survey thrips species in three Vica faba fields located at different sites in Biskra, identify them to species, and determine the relative abundance of each species..

\section{MATERIALS AND METHODS}

Study area: The study was carried out at the years 2010-2011, from December to marsh, at three sites. Two of the sites were commercial fields of broad bean, located at Sidi Okba and M'ziraa. The plots were managed under normal cultural practices for the area, where pesticides were applied against thrips and aphids, and plants were fertilized. The third site was located at El-Outaya were the growers did not use chemicals for controlling pests in the field (Fig. 2). The area of each plot was $400 \mathrm{~m}^{\mathrm{k}}$, each field was divide on 4 equal size plots.

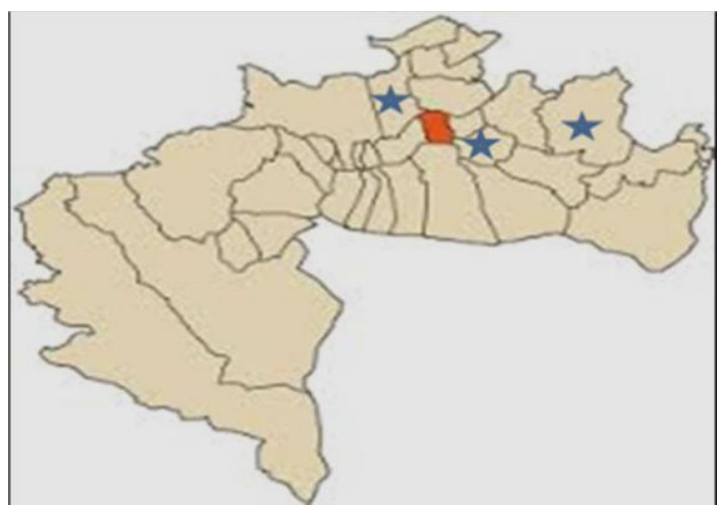

Fig. 2: Locations $\left(^{*}\right)$ of sampled broad bean fields in Biskra.

Thrips sampling: Only adult thrips were sampled for identification, they were collected from the plants and from flowers.

For sampling thrips from plants, adults were collected from 40 plants randomly selected from each plot, by shaking the plant over a white plate 10 times, thrips where collected using a fine brush into a labeled vial ethanol at $70 \%$. 
For sampling thrips from flowers, one flower was cute from the same sampled plant, then immediately transferred in a plastic bag to the laboratory.

Thrips were sampled every two weeks at same day.

Laboratory studies : To dislodge species thrips from flowers, those plant part were cut in a dish containing water, to wash them and take petals and other parts out of the dishes. Under dissecting microscope thrips were immediately transferred using a fin brush into labeled vial containing 70\% Ethanol.

All thrips collected were examined under dissecting microscope, counted and separated for eventual identification.

Thrips collected from the whole plant and from flowers, were mounted on slides with Hoyer's medium (50 $\mathrm{ml}$ water, $30 \mathrm{~g}$ gum arabic, $200 \mathrm{~g}$ chloral hydrate, $20 \mathrm{ml}$ glycerine), and identified under a compound microscope using published keys (e.g., Mound 1999, Moritz \& al. 2001).The slides preparation and thrips identification was realized in the laboratory of light microscopy in the department of entomology and plant pathology, of the university of Tennessee, Knoxville.

\section{RESULTS AND DISCUSSION}

Thrips survey at the three Biskra broad bean fields: Various species of thrips were identified on broad bean crops in the three sites of Biskra (fig 8).

The total thrips collected during the investigation period was 3867 from 6 genera and two families,
$82 \%$ of species belonging to the Thripidae family, represented by: Odontothrips loti,Thrips angusticeps, Thrips physapus and Frankiliniella occidentalis. However $18 \%$ of species belonging to the family of Aeolothripidae, whitch are , Aeolothrips intermedieus, Rhipidothrips gratiosus and Melanthrips fuscus (tab I).

A high proportion of thrips feeding from flowers (tablell), they are also collected from the whole plant after shaking.

Thrips distribution on the three braod bean fields: The total number of thrips species collected during all the sampling period was higher on M'ziraa with the average total of 1808 thrips, flowed by their total number in Sidi Okba 1039. El-Outaya field presented the low number with 1020 thrips species (fig 5).

Odontothrips loti was the most abundant species on broad bean crops with the rate of $48 \%$ of the total thrips collected. It was followed in numbers by Thrips angusticeps with the rate of $22 \%$, Aelothrips intermedius with the rate of $10 \%$, Thrips physapus with the rate of $9 \%$, Frankliniella occidentalis with $3 \%$, and Melanthrips fuscus with the rate of $5 \%$ (fig 3 ). Finaly, Rhipidothrips gratiosus with the rate of $3 \%$

All thrips species were present in the three sites. Odontothrips loti species was the most abundant on M`ziraa and Sidi Okba fields, but for El-Outaya Aeolothrips intermedius was the most abundant (fig $6)$.

\section{Table I Species found at Biskra region and their taxonomy}

\begin{tabular}{|l|l|l|}
\hline Species & Family & Occurrence \\
\hline $\begin{array}{l}\text { Odontothrips loti (Haliday) } \\
\text { Thrips angusticeps (Uzel) } \\
\text { Frips physapus (Linnaeus) }\end{array}$ & Thripidae & \\
\hline $\begin{array}{l}\text { Aeolothrips intermedius (Bagnall) } \\
\text { Melanthrips fuscus (Sulzer) } \\
\text { Rhipidothrips gratiosus (Uzel) }\end{array}$ & Aeolothripida & $18 \%$ \\
\hline
\end{tabular}


Table II Thrips occurrence on the plant and flowers 0 the broad bean

\begin{tabular}{|l|c|c|}
\hline Species & Plant part (\%) & Flowers (\%) \\
\hline Odontothrips loti & 35 & 65 \\
\hline Thrips angusticeps & 28 & 72 \\
\hline Thrips physapus & 44 & 56 \\
\hline $\begin{array}{l}\text { Frankliniella } \\
\text { occidentalis }\end{array}$ & 08 & 92 \\
\hline $\begin{array}{l}\text { Aeolothrips } \\
\text { intermedius }\end{array}$ & 19 & 81 \\
\hline Melanthrips fuscus & 11 & 89 \\
\hline $\begin{array}{l}\text { Rhipidothrips } \\
\text { gratiosus }\end{array}$ & 55 & 45 \\
\hline
\end{tabular}

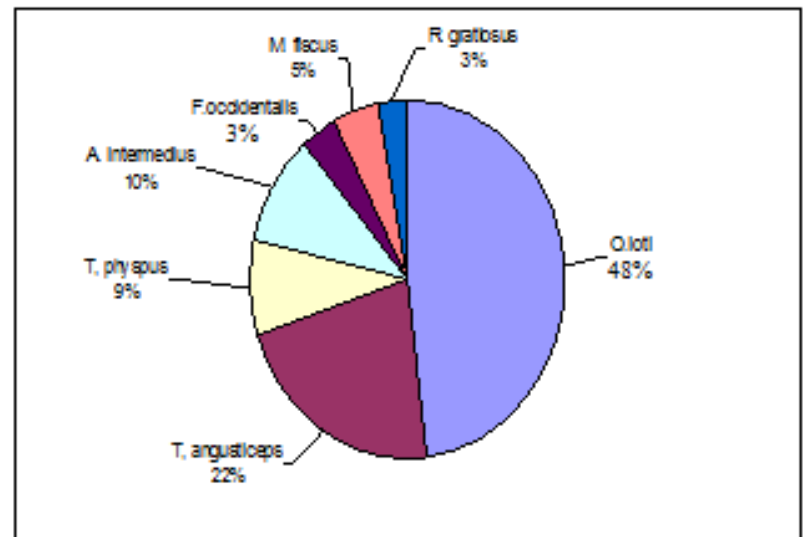

Fig. 5: Proportions of thrips species on broad bean at the three sites in Biskra.

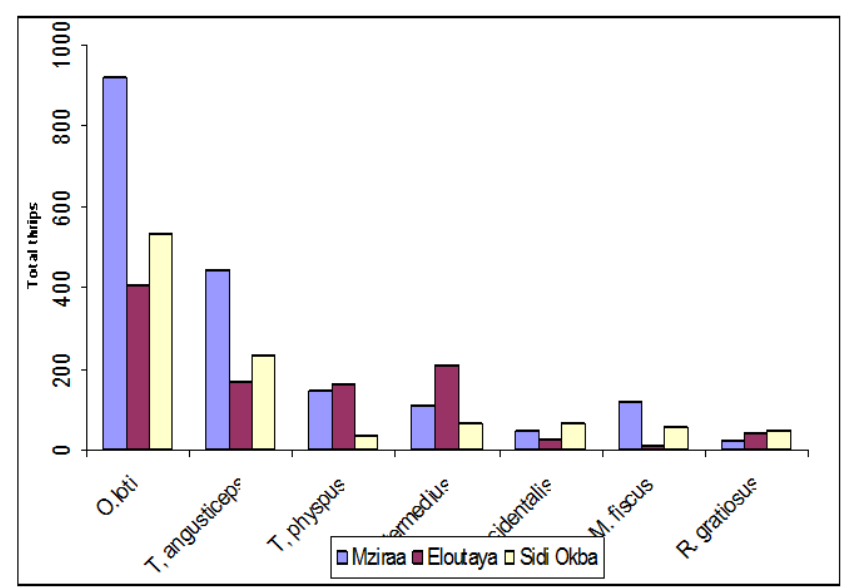

Fig. 6: Thrips species distribution at each site.

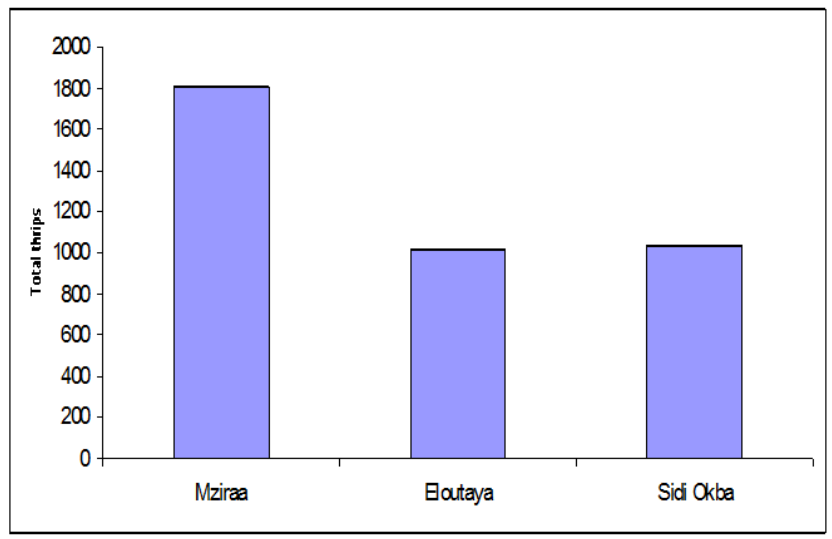

Fig. 7: Total thrips numbers at each site.

\section{DISCUSSION}

Thrips species at the three Biskra sites and their distributions: The survey show that seven thrips species were found on the broad bean of Biskra province, the same species are recorder on Citrus plant by Belaam and Boulaehia-kheder (2012) in Tunisia, and by zur Strassen (1968) in Marroco.

The genus Odontothrips is listed by many authors, such as Presnier (1958), as a leguminous pest, this genus is reported as pest feeding from flowers legumeous by Pitkin (1972).

$T$. angusticeps is recorded as bean pest by Biddle (1991) and breeds from flowers and leaves, the same author records that it's appeared to associate at rather high frequencies with legumeous such as broad bean and peas and it is related to the presence of the plant Synapsis arvensis in the broad bean fields, as records by Lewis(1973) this plant is a host for this species.

Since Thrips physapus is listed as polyphagus insecte (Pobożniak \& Sobolewska, 2011) A. intermedius, and $F$. occidentalis are polyphagous also (Lewis, 1993)

For F. occidentalis, this thrips breeds and feeds on leaves and within flowers in broad bean, this is reported by O'Donnell (2007), feed also from pollen flower and leafs It is a mites predator and can transmit tospovirus diseases. It is a highly polyphagous pest (Lewis, 1993).

For A. intermedius, it was found on different part of the plant, it is a facultative pest, adult feeds on flowers this mentioned by (Sabelis \& Van Rijn, in 
Lewis 1997) but larva can be thrips predators (Bruce \& al, 1998).

For $R$ gratiosus, there is no recorded damage for this species; It could be an occasionally pest on broad bean.

Lewis (1973) reports that thrips are known as polyphagus pests they can have several host plants and attack different part of the plant, however, O. loti, $T$. angusticeps and $M$. fuscus were found both either in the flowers and the other plants part, the three species are recorded by authors as species breading from leguminous flowers, there collection from the plant, could be due to there high number in the flower and the ability to dislodge them from flowers by shaking the plants, since there number still higher in the flowers, but this thrips can be found within the developing leaves of the growing point occasionally.

Relation between thrips composition and braod bean of Biskra: The diversity of thrips species on broad bean came probably from the fact that Biskra is a dry area offering the best condition for thrips development, Lewis (1973) and Ananthakrishanan \& Gopichandran (1993) reported that this kind of climat is convenient for thrips development, Also the three fields were surrounded by other crops, such as tomato and pepper greenhouses, onion, garlic crops and adventives plants such as Synapsis arvensis, this plants can host thrips species, and thrips can flight to change there host plant (Lewis, 1973).

Another fact is the broad bean nutriment compositions, the plants are rich on nutriments especially nitrogen, they fixes azote air, this had a good affect against thrips population development and plants were highly attractive to these species. However, Brown and Scott (2002) shows that increasing in azot soil fertility has good effect on thrips development and plant attraction, by studying relationship between plant composition nutrient and thrips infestations level.
Thrips species Repartition among the three fields: The abundance of thrips was more important at M ziraa, followed by Sidi Okba, in these tow fields chemical pesticides applied for thrips and aphis suppress may harm benefic predators, pest are more resistant, and present a high development, this was proved bys the distribution of thrips species in ElOutaya field, where $A$. intermedius was the abundant one, avoiding chemicals, this predator was preserved, it can prey other thirps pests (Bruce, 1991), and various species of thrips were offered to the larvae of $A$. intermedius (Ananthakrishnan (1984).

\section{CONCLUSION}

Various thrips species were found at Vicia faba fields in the Biskra province, six species are phytophagous and one predator.

Odontothrips loti and Thrips angusticeps are the most abundant species they may be classified as harmful organism for this crop.

Growers of Biskra must know these species and their ability to destroy crop productions especially by transmitting dangerous viruses, these in order to protect their productions. The example of El-Outaya field is encouraging to use organic agriculture preserving predators species. That can, with their only effect control pests.

This work is just a survey of broad bean thrips at Biskra, Since other studies must fellow it, to have more information about thysanopetera species whitch can cause direct damage by destroying cells plants, or indirect by viruses transmission.

Also it is important to study the biology of these species, their dynamics, and a survey of species feeding from plant surrounding Vicia faba crops, to control this pest and control the damages and prevent economic loses. 


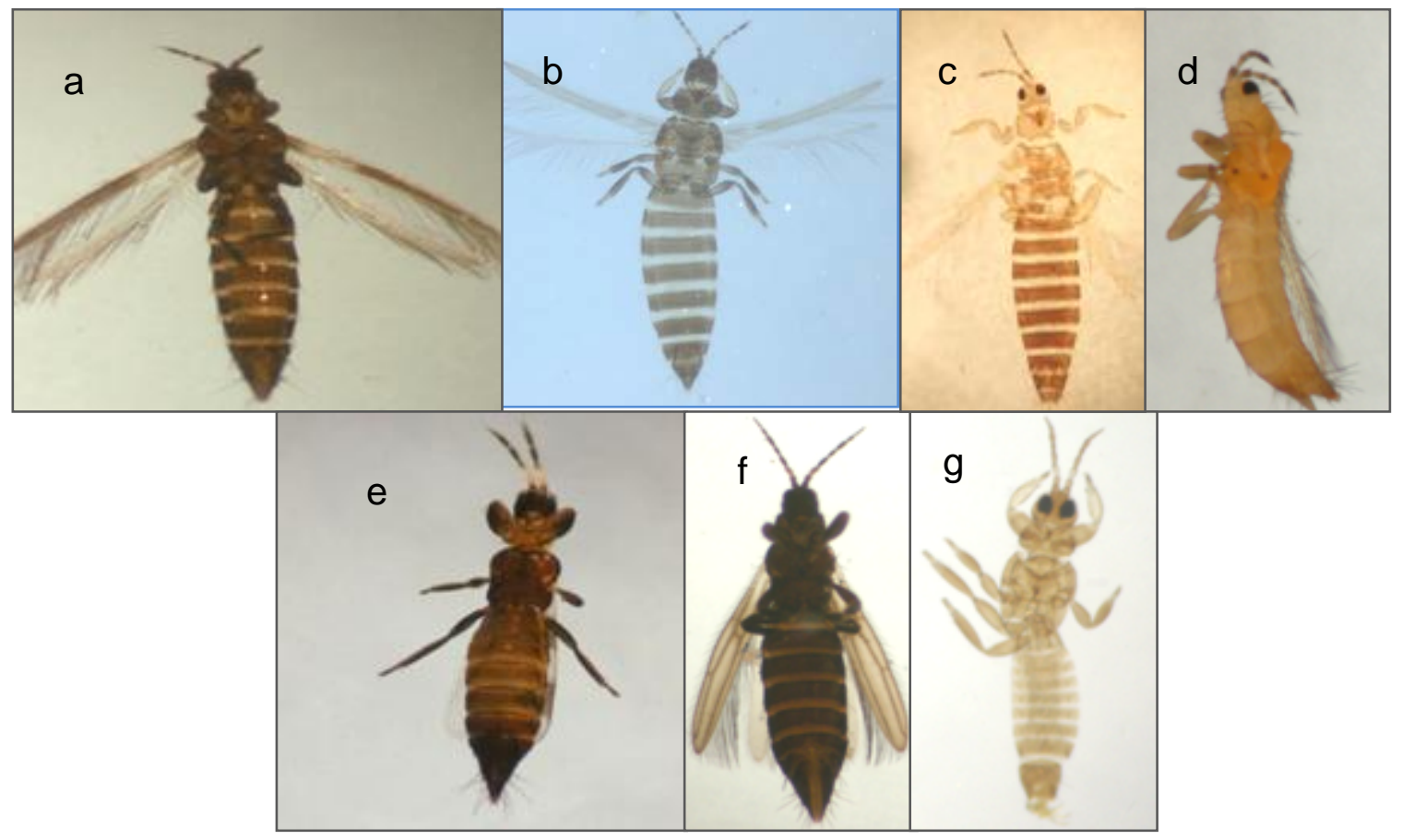

Fig. 8: Thrips species on broad bean in Biskra research plots.

a: Odontothrips loti, b: Thrips angusticeps, c:Thrips physapus,d: Frankliniella occidentalis, e: Aeolothrips intermedius, $\mathrm{f}$ : Melanthrips fuscus, g: Rhipidothrips gratiosus

\section{REFERENCES}

Ananthyakrishanan, T.N., (1984), Bioecology of thrips, Indira Pub.,house, USA 233p.

Ananthakrishanan, T.N. \& Gopichandran R., (1993) Chemical ecology in thrips-host plant interactions, Science, Pub, Inc, USA, 125p.

Anonymous, (2002), Diagnostic protocols for regulated pests. Protocoles de diagnostic pour les organismes, réglementés, OEPP/EPPO, 32, 241-243

Brink, M, Belay G, (2006), Céréales et légumes secs (ressources végétales de l'Afrique Tropicale Fondation PROTA Wageningen, Pays Bas 327p.

Baily, S. F., (1957), The thrips of California, part I: suborder Terebrantia, Bull.Calif.Insec. Surv.4 (5)139220.

Belaam, I., Boulaehia-kheder S., (2012). Inventory of Thrips Species in Citrus Orchards. Tuni. J. of PI. Prot.. 45. (7), No. 1,
Bournier, J. P., (2002), les Thysanoptères de cotonniers, CIRAD.CA, Montpellier.105p

Biddle, McKeow M. B., (2007) Pests and Diseases of Peas and Beans. Ed Masson, 128p

Ching-Lin Wang, Feng-Chy Lin, and Hsien-Tzung Shih, (2010), Species of Frankliniella Trybom (Thysanoptera, Thripidae) from Asian-pacific Area. Zoological studies 49(6): 824-838.

Hamadeche, A. et Oufroukh A., (1994) Rapport de mission effectuée du 10 au 13avril 1994 à Biskra, ITGC et INPV, Ministère de l'Agriculture, Alger, 12 p.

Lewis T., (1973) Thrips, their bilogy, ecology and economic importance, Academic Press London \& New York Inc. 349p.

Lewis, T (1997), Thrips as crop pests, Cab. International. UK, 740p.

Majid-Mirab-balou and Zue-xin Chen, 2011, The Megalurothrips genus-group in Iran (Thysanopetra: Thripidae),Mun, Ent.Zool.Vol.6, N 2. 944-952. 
Masumoto, M., (2010) Key to Genera of the Subfamily Thripinae (Thysanoptera: Thripidae) Associated with Japanese Plant Quarantine, Res.B ull. PI. Prot. Japan No. $46 p$

Morisson, G. D., (1957) A review of British glasshouse Thysanoptera. Trans. R. Ent. Soc. Lond. 109. 16Pt. $54 \mathrm{p}$.

Moritz, G., (1994) Pictorial key to the economically species of Thysanoptera in central Europe. Bull.OEPP\EPPO Bull. 24, 181-208.

Mound, L. A. (2007) Thysanoptera (Thrips) of the World a Checklist. Commonwealth Scientific and Industrial Research Organization, Entomology, Canberra, Australia. au/thysanoptera/worldthrips.html http://www.ento.csiro.

Mound, L.A.and Kibby, (1998) Thysanoptera, An identification guide. 2nd Ed., CAB.INTERN, 70P.

Nakahaara S., (1994) The Genus Thrips Linnaeus (Thysanoptera:Thripidae) of the new world. Unit. stat.dep. agric. Techn.bull. N 1822, 190p.

Nickel, D. A, (2008) commonly intercepted thrips at US ports-of-entry from Africa, Europe and the Mediterranean. III the genus Thrips Linnaeus, 1758(Thysanoptera:Thripidae). Proc.Entomol.Soc Wash., 110(1), 165-185
O'Donnell, C. A., (2007) Color Morphology of the Western Flower Thrips of California and Virus-vector Ed UMI $129 p$,

Pitkin, B.R.,(1972) A revision of the flowers-living genus Odontotjrips amyot ans servile (Thysanoptera: Thripidae), Bull. Of the British museum (national history) entomology, 26. (9)396-402.

Pobożniak M., Sobolewska A. (2011) Biodiversity of thrips species (Thysanoptera) on flowring herbs in Cracow, Poland Jour,pl. prot. Resea 51, (4) pp 393-399

Presnier, H., (1960) A mongraphie of the Thysanoptera of the Egyptian deserts, Pub. Inst.desert, Elmataria. Le Caire. 13. $541 \mathrm{p}$

Saxena, MC., (1999) Status and scope for production of faba bean in the Mediterranean countries. Options Méditerranéennes, Ser. Séminaires ; 10 : 15-20.

Strassen, R.Z, (1968), Ökologische und zoogeographische Studien über die FransenflüglerFauna des südöstlichen Marokko, kt., 125 Seiten, 48 Abb., 7 Karten, 125p

Triplehorn, C.H. and Johnson N.F., (2005) Borror and Delong's introduction to the study of insects, $7^{\text {th }}$ Ed,Thomson, brroks/cole, 333-340, 864pl

Zeghoueane, O. (1991) The situation of fava bean (vicia faba L.) in Algeria. CIHIEAM, Options Mediterraneennes, 